w słowa Pana Jezusa znaczenia, które mimo wszystko jest z trudem wypracowane i budzi podejrzenie niezgodności $z$ prawdą. Najmniej prawdopodobnym pod względem psychologicznym i ze względu na kontekst jest thumaczenie Noli me tangere. Me mou haptou znaczy: „Nie chciej mnie zatrzymywać!“ Miłość wycisnęła ci łzy i skłoniła przynieść do grobu wonne-olejki, aby zatrzymać Mą duszę dłużej na ziemi. Ta sama miłość, lecz oświecona wiarą, każe ci radować się, bo zwyciężyłem śmierć i wracam do Ojca wskazując drogę wszystkim zbawionym.

Ks. SEWERYN KOWALSKI.

Warszawa.

\title{
WIECZERZA PAŃSKA W I. LIŚCIE ŚW. PAWKA DO KORYNTIAN
}

Eucharystia od pierwszych chwil istnienia chrześcijaństwa stała się ośrodkiem życia religijnego. Czytamy w Dziejach Apostolskich, że chrześcijanie ,trẃwali $w$ nauce apostolskiej $w$ uczestnictwie lamania chleba $i$ modlitwach... $(2,42)$, codziennie takie przebywali pospolu w światyni, po domach zaś łamiąc chleb, pożywali pokarmy z weselem i prostota serca, chwalac Boga... $(2,46)$. A pieruszego dnia po szabacie, gdyśmy się zeszli na łamanie chleba..." $(20,7)$. W przytoczonych tekstach mamy wzmianke o zebraniach Eucharystycznych, zwanych „tamaniem chleba" lub „Wieczerza Pańska“ (1 Kor. 11, 20)., na których starano się $\mathrm{z}$ całą możliwą wiernością (odtworzyć Osstatnią Wieczerzę Pańską. Treścią tych zebrań były: Uczta, wykład Pisma św., konsekracja chleba i wina z Komunią św. i modlitwy odmarwiane lub śpiewane. Wszystkie te czynności zebrań religijnych pierwszych chrześcijan zostały objęte później nazwą Mszy św. W czasie prześladowań z powodu obowiązku tajemnicy (disciplina arcani) i rozpoczęcia praktyki pokutnej, część dydaktyczną Mszy św. oddzielono od właściwej ofiary i modlitw $z$ nią związanych. Cześś pouczająca kończyła się modlitwą i błogosławieństwem biskupim. Właściwa Msza święta rozpoczynała się pocałunkiem pokoju i ofiarą chleba i wina wraz z przeistoczeniem, a kończyła się Komunią św., będącą spełnieniem 
ofiary Eucharystycznej i jednocześnie wyrazem łączności wszystkich wiernych (Communio).

Z ofiarą Mszy św. łączyły się ściśle w początkach chrześcijaństwa uczty bratnie, zwane agapami ${ }^{1}$ ), będące symbolem miłości i jedności wśród wiernych.

„Uczta nasza - pisze Tertulian ${ }^{2}$ ) - imieniem swym pokazuje, czym jest, nazywa się tak, jak u Greków miłość (ağape). Św. Chryzostom (Hom. in Resur.) ${ }^{3}$ ) zaś tàk te uczty nam przedstawia: „Wierni po wspólnym wysłuchaniu kazania i ùczestniczeniu w Tajemnicach nie rozchodzili się zaraz, ale bogatsi przyniósłszy $z$ domu potrawy ugaszczali uboższych i wszyscy razem w samym kościele używali jednego stołu i jednej uczty. W ten sposób przez wspólność stołu i poszanowanie świętego miejsca węzły miłości się zacieśniały z wielką radością i pożytkiem wielkim".

O podobnej uczcie miłości połączonej z Eucharystią, wspómina św. Paweł w pierwsźym liście do Koryntian, (rozdział XI, 17-34), opisując ją w ten sposób: ${ }^{4}$ )

A nakazujac to, nie pochwalam, ze zebrania wasze zamiast się polepszać (staja się) gorsze.

Przede wszystlim bowiem słysze, że gdy gromadzicie się w kościele, panuja wśród was spory.

I po części wierzę w to.

Boć potrzeba, aby i różnice zdań byly między wami,

iżby dali się poznać ci, którzy wypróbowani sq wśród was.

Otóż gdy się w tym właśnie schodzicie celu,

nie jest to już spożywanie Wieczerzy Pańskiej.

Kazdy bowiem własna wieczerze wpierw bierze do jedzenia,

przy'czym jeden głoduje, drugi popija.

Czyż nie macie domów do jedzenia i picia!

Czyż przez to nie lekceważycie światyni Bożej,

$i$ nie zawstydzacie tych, którzy nic nie maja?

Cóż wam powiem, czy mam was chwalić? Nie chwalę!

Albowiem otrzymatem od Pana, co tez wam przekazalem,

1) Gdy wspominam o agapach, mam tu na myśli uczty braterskie złączone $z$ święceniem Eucharystii, a nie urządzane z racji chrztu, czy pogrzebu lub też innych uroczystości.

2) Apologetyk (P. O. K., tom XX. Poznań, 1947), str. 161.

s) Tamże str. 162 .

$\left.{ }^{4}\right)$ Według tekstu greckiego (Merk, S. I., Novum Testamentum, Roma, 1944). 
ze Pan Jezus owej nocy, której zostat wydany,

wziąt chleb, a dzięki uczyniwszy, potamat i rzekt:

TO JEST CIALO MOJE,

ZA WAS (OFIAROWANE),

TO CZYŃCIE NA MOJA PAMIAZTKE.

Podobniez wzią po Wieczerzy i kielich, móviac:

TEN KIELICH STANOWI NOWE PRZYMIERZE

WE KRWI MOJEJ,

ILEKROC GO PIC BEDZIECIE,

CZYNCIE TO NA MOJAZ PAMIATKEE.

Hekroć bowiem bẹdziecie chleb ten jedli i kielich ten pili, głosić bẹdziecie śmierć Pana, dopóki nie przyjdzie.

Ktoby tedy jadt ten chleb lub pił kielich Pański niegodnie, ten zawini wobec Ciala i Krubi Panskiej.

Niech zatem czlowiek bada samego siebie

a potem niech je ten chleb i niech pije z tego kielicha.

Kto bouviem je $i$ pije (niegodnie), potepienie sobie gie i pije,

bo nie odróżnia Ciała (Pańskiego).

Dlatego tylu wśród was jest stabych i chorych

i tylu umiera!

Gdybyśmy zaś sami siebie sądzili, nie bylibyśmy sq̨azeni.

Lecz jessli Pan sadzi, to karci w tym celu, ażeby nas z tym światem nie spotkało potepienie.

A gdy się schodzicie na uczte, bracia moi!

oczekujcie przeto jedni drugich.

Jeśli ktoś głodny, niechaj je w domu,

abysisie sie nie schodzili na potepienie.

A resztę zarządzę, gdy osobiście przybędę.

W powyższym ustępie rozróżnić możemy trzy części: pierwsza zawiera skarcenie Koryntian za nieodpowiednie zachowanie się na zebraniach eucharystycznych, druga przypomnienie Wieczerzy Wielkoczwartkowej, trzecia zlecenia dotyczące przygotowania się na Ucztę Pańską.

1) Nagana za naduzycia na Uczcie Eucharystycznej (w. 17-22). Św. Paweł w czasie pobytu w Koryncie wyłożył naukę Kościoła o Eucharystii, zachęcając do godnego obchodzenia pamiątki ustanowienia Najświętszego Sakramentu i przyjmowania Komunii świętej. 
Uczty buatnie połączone z Eucharystią miały być w myśl wskazań Jezusa wyrazem miłości i jedności między wiernymi oraz środkiem wspomagania i odżywiania biednych. Koryntianie tak biedni jak i bogaci gromadzili się w domu specjalnie przeznaczonym na zebrania religijne, które św. Paweł nazywa „Ekklesia“, gdzie, dzieląc się z ubo- gimi, spożywano przyniesione dary i przystępowano do Stołu Pańskiego.

W czasie, w którym ten list był pisany, wspólny posiłek poprzedzający branie udziału w tajemnicy Eucharytii nie miał w sobie nic przeciwnego uszanowaniu i nie był nadużyciem, bo celem tego zwyczaju było jak najdokładniejsze odtworzenie porządku i szczegółów Ostatniej Wieczerzy. Dłatego nie za nieprzestrzeganie ieiunium Eucharisticum karci św. Paweł Koryntian, lecz za nieodpowiednie zachowanie się w czasie uczt religijnych, które wkradły się do ich gminy, a nie odpowiadały charakterowi Wieczerzy Pańskiej. (Nie pochwalam, że zebrania wasze zamiast się polepszać, staja się gorsze, w. 17). Lekkomyślni i powierzchowni chrześcijanie mimo wiary, którą w teorii posiadali, zamieniali tajemnicę Najświętszą w rodzaj uczty pogańskiej. Zgromadzeni nie czekali jedni na drugich: bogatsi zasiadali do stołu oddzielnie, kłócili się nawzajem, prowadząc dysputy na temat nowej religii i pogardzając biedniejszymi. Ci ostatni, skrępowani pracą i wolą niedobrego chlebodawcy, nie zawsze mogli się jawić na czas, przychodzili często wtedy, gdy bogatsi byli już nasyceni, a náwet. i zbyt weseli, zjadłszy ze swymi towarzyszami pokarmy, które przynieśli dla podzielenia się z ubogimi. Jeszcze ostrzej karci pierwszych chrześcijan św. Jakub za robienie różnicy między bogatymi a ubogimi na niekorzyść tych ostatnich. Caytamy w jego liście $(2,1-6)$ :

„Bracia moi, czyż wy posiadacie jeszcze wiare w Pana naszego Jezusa Chrystusa uwiel̄bionego, jeśli ogladacie się na ludzi? Gdyby bowiem na zebranie wasze przyszedł maż ze złotym pierścieniem na palcu $i$ we wspaniałej szacie, a wszedtby równiez ubogi w wytartym odzieniu, a wy zwracajac uwage na tego, który ma wspaniala szatę, powiedzielibyście mu: Ty usiadź sobie tutaj wygodnie! natomiast biedakowi: ty stań albo siadź sobie u nóg moich! Czyż to słusznie, ze taka różnice róbicie u siebie, moi ukochani bracia! Czyż Bóg nie wybral ubogich $w$ oc.ach śurata, aby byli bogatymi $w$ wierze $i$ dziedzicami królestwa, które przyobiecał tym, co Go miłuja? Wy zaś znieważyliście ubogiego".

Zebrania religijne, a przede wszystkim eucharystyczne, które miały być ośrodkiem i symbolem jedności i równości między wiernymi 
stały się dla Koryntian, jak innych chrześcijan sposobnością do upokarzania uboższych braci i do nierówności społecznych. Dlatego słusznie św. Pawel karci ich, stwierdzając, że uczty takie nie są przypomnieniem Wieczerzy Pańskiej (Kyriakon deipnon) lecz frywolnymi biesiadami pogańskimi. Nie wiemy, czy św. Paweł pisząc: ,Reszte zarzadzę, gdy osobiście przybędę" (w. 34) unormował ten niewłaściwy zwyczaj, czy też go usunął. Ponieważ podobne wypadki nadużycia na ucztach eucharystycznych powtảrzały się, Kościół, ảby im na przyszłość zapobiec oddzielił agapy od właściwej ofiary Eucharystycznej, nakazując, aby tę ostatnią odprawiano rano.

\section{Ustanowienie Uczty Eucharystycznej przez Pana Jezusa} (w. $23-26$ ).

Skoro tylko św. Paweł dowiedział się, że Koryntianie spaczyli charakter Wieczerzy Chrystusowej, pragnie wspomnianym brakom i niedomaganiom zaradzić i zło naprawić przez wskazanie właściwego sensu Uczty Pańskiej. Dlatego powtarza naukę Kościoła o Eucharystii, którą głosił iw czasie swego pierwszego pobytu w Koryncie (ok. 52 r.). Znał on dobrze historyozne zḍarzenie nocy Wielkoczwartkowej $\mathrm{z}$ bezpośredniego objáwienia Bożego i tradycji Apostolskiej. Stąd też zanim rozpocznie opowiadać o samym ustanowieniu Najświętsżego Sakramentu zaznacza, że głosi naukę nie swoją, lecz Chrystusa (w. 23) ${ }^{\text {s) }}$. Świadectwo jego jest obok Ewangelii jednym z najstarszych dokumentów pisanych i dla tego ma dla nas wielkie znaczenie historyczne. O tym samym fakcie opowiadają nam prócz niego Ewangelie synoptyczne. Opowiadanie św. Lukasza, ucznia św. Pawła, jest prawie dosłownym powtórzeniem pierwowzoru Pawłowego. Pewne tylko różnice, ale nie istotne w przedstawieniu Wieczerzy Pańskiej zachodzą między redakcją św. Pawła a Ewangeliami Mateusza i Marka.

Porównajiny teksty. Ewangelii z opisem Apostoła.

Według św. Mateusza i Marka konsekracja chleba i wina odbyła się w czasie Wieczerzy (esthionton de auton). Z opisu zaś św. Pawła

$\left.{ }^{5}\right)$ P. Ketter: Korintherbriefe (Herders Bibelkommentar für das Leben erklärt), - Freiburg in Br. 1937, B. XIV, str. 268 nn. i E. B. Allo: Saint Paul, Premiere Epitre aux Corinthiens, str. $292 \mathrm{nn}$. Słowo parala m ba no odpowiada hebr. qibbel = otrzymać, podobnie jak Mojżesz otrzymał Torę i przekazał ją swoim następcom,' (hebr. masar), św. Pawel użył paradidomi= podać, przekazać, porównaj: Strack-Billerbeck: Kommentar zum N. Test. aus Talmud u. Midrasch, str. 443, München 1920, B, 3. 
i Łukasza wynika, że konsekracja chleba miała miejsce podczas Wieczerzy, a wina pod koniec tejże (w. 25, Łuk. 22, 20).

Gdy jednak wyrażenie św. Pawła „podobnież" (hosautos) odniesiemy nie do czynności Jezusowej, lecz do słowa ",po Wieczerzy“ (meta to deipnesai), wtedy według świadectwa św. Pawła nie tylko konsekracja wina odbyła się pod koniec uczty paschalnej, ale i chleba. A jeśli tak było, to Judasz, zdemaskowany przez Pana Jezusa (Jan 13, 35 i Mat. 26, 23) nie był obecny przy ustanowieniu Najświętszego Sakramentu, nie przyjął Komunii św. i nie otrzymał święceń kapłańskich. Wskazywałyby na to również słowa św. Jana: ,on zaś spożywszy ka'valek ,chleba", natychmiast wyszedt $(13,3)$ - w połączeniu ze świadectwem Mateusza $(26,21-26)$ i Marka $(14,18-21)$. Z tych tekstów wynikałoby, że Judasz po spożyciu gorzkich ziół, chleba przaśnego jeszczè nie konsekrowanego i baranka paschalnego, oraz wypiciu trzeciego kielicha, wyszedł $z$ Wieczernika ${ }^{6}$ ). Rytual żydowski zezwalał jeszcze na czwarty i piąty kielich. I w tym to czasie prawdopodobnic Pan Jezus rozpoczął konsekracje chleba i wina, która nastąpiła wprawdzie w ramach uczty paschalnej, lecz już po spożyciu głównych jej potraw. Stąd też wyrażenie synoptyków, że Jezus rozpoczął konsekrację w czasie Wieczerzy zgadzałoby się ze świadectwém św. Pawła, który wspomina, że była ona pod koniec Wieczerzy.

Charakterystyczną cechą redakcji św. Pawła są słowa Pana Jezusa wypowiedziane po konsekracji: „To czyńcie na moja pamiatkę" (w. 24 i 25$)^{7}$ ), których nie mają dwaj Synoptycy. Jako równoważnik Pawłowego wyrażenia możnaby uważać słowa: ,bierzcie i jedzcie“... „pijcie z tego wszyscy“ u św. Mateusza $(26,27$ i 27) i św. Marka $(14,22)$ bo tak zdanie Apostoła jak i Ewangelistów nadają całej tej czynności ten sam charakter liturgiczny.

Formuła konsekracji chleba u św. Pawła: ,to jest Ciało moje, litóre za was" (w. 24) w pierwszej części brzmi identycznie z tekstem Mateusza i Marka i jest stwierdzeniem prawdziwej obecności Chrystusa pod postacią chleba. Następne słowa, „,które za was" (to hyper hymon) uwydatniają ofiarniczy charakter Eucharystii. Św. Lukasz uzupełnia je

6) H. Preisker w artykule ,der Verrat des Judas und das Abendimahi“ (Zeitschrift für Neut. Wissenschaft, 1942, str. 151-155) uważa, że porządek wierszy u Łukasza (22, 25, 28-30, 21-23) został zmieniony przez późniejszą trađycję chrześcijańską, a na podstawie tekstów Łuk. 22, 21 i Ján 13, 26 należałoby przyjąć, że Judasz przyjął Komunię św.

$\left.{ }^{7}\right)$ Por. ks. Szczepański Wł. T. J.: „Eucharystia w świetle listów św. Pawla" (Przegląd Powszechny 1924, str. 12 i n). 
wyrażeniem ,didomenon“ (ofiaruje się, wydaje się), które posiadają również inne lekcje pierwszego listu do Koryntian ${ }^{8}$ ).

Św. Pawel w formule konsekracyjnej wina, która weszła do kanonu Mszy św., jeszcze wyraźniej akcentuje ideę ofiarniczą Wieczerzy Pańskiej. Brzmi ona: ,ten kielich stanowi nowe Przymierze we krui mojej" (w. 25). Te sama myśl podali nam Synoptycy przez dodanie do formuły konsekracyjnej wina: „to jest krew moja Nowego Testamentu“ słów: „która za wielu będzie wylana na odpuszczenie grzechów" (Mat. 26, 28 i Marek 14, 24). To co Mateusz i Marek wyrazili w prostej formie, Apostol podaje przez metonimie (continens pro contento). Kielich $z$ winem, które dzięki wszechmocnemu słowu Chrystusa przemieniło się w Krew Nájświętszą, staje się podstawą Nowego Przymierza między Bogiem a ludzkością $\left.{ }^{9}\right)$. Mojżesz przy zawarciu przymierza kropil lud krwią zwierząt ofiarnych (Wyjść. 24, 8), Chrystus krwią własną przypieczętowuje Nowe Przymierze w miejsce Starego. Dobitniej charakter ofiary krzyżowej w Eucharystii podkreślił św. Paweł w następnych słowach: ,ilekroć bowiem będziecie jedli ten chleb i kielich pić bẹdziecie, śmierć Pana będziecie opowiadali“ (w. 26). Zdanie to wraz z poprzedzającym wyrażeniem: „to czyńcie na moja pamiatkę", które Apostol dwa razy powtarza ma doniosłe znaczenie, albowiem na nich opiera się istota Uczty Eucharystycznej, jako instytucji stałej.

Słowa: „to czyńcie na moja pamiatkę", wyrażają wolę Jezusa. który pragnął, aby czynność przeistoczenia powtarzała się zawsze w gronie Jego uczniów i wiernych. A odprawienie Ostatniej Wieczerzy, w której Chrystus antycypował ofiarę Wielkopiątkową, nie będzie już pamiątką baranka zabitego na ofiarę, lecz pamiątką nieskończenie doskonałej ofiary Jezusa, złożonej na krzyżu za całą ludzkość. Myśl ta pı zewija się prawie we wszystkich listach św. Pawła: „Albowiem jako nasza Pascha ofiarowan jest Chrystus (1 Kor. 5, 7), umilowat was i wydat samégo siebie za nas na dar i na ofiare (thysia) Bogu (Efez. 5, 2). Jego postanowit Bóg ofiara przebłagalna przez wiare we krwi Jego (Rzym. 3, 25).

8) Oprócz „didomenon" niektóre lekcje mają „klomenon, thryptomenon“; wyrażenia te jeszcze silniej podkreślają moment ofiarniczy Eucharystii. Por. Sickenberger: Die Briefe des Heiligen Paulus an die Korinther und Römer. (Die Heilige Schrift des N. Test., VI), Bonn 1932, str. 52-56.

$\left.{ }^{9}\right)$ Krew Zbawiciela jest antytezą do krwi zwierząt ofiarnych w St. Testamencie. 
W czasie Ostatniej Wieczerzy, Pan Jezus, wyprzedzając Wielkopiątkową ofiarę na krzyżu, złożył ją pod sakramentalnymi postaciami, gdy wypowiadał showa ,to jest Ciało moje, które się za was ofiarowuje, ten jest kielich krwi mojej, która za was będzie wylana". A co wówezas dokonał przez antycypację, to czynią kapłani dziś na oltarzach w myśl Jego polecenia ,to czyńcie na moją pamiątkę“ przez ponowienie i uobecnienie Ofiary krzyżowej ${ }^{10}$ ).

W Wielki Czwartek złożył Zbawiciel samego siebie w ręce. Apostołów - Kapłanów, stając się po wszystkie czasy żertwą i obiatą, którą oni ofiarują Bogu Najwyższemu dla przebłagania, zadośćuczynienia, dziękowania i uproszenia łaski Bożej. Św. Pawel szozególnie podkreślił słowa Jezusa: „to czyńcie na moja pamiątę", aby obok momentu ofiarniczego uwydatnić jeszcze moment społ̌eczny Eucharystii. Wraz z kapłanami mają składać ofiarę i wierni. Pierwsi, którzy otrzymali władzę konsekrowania, mają tę ofiare sprawować przez przeistoczenie chleba i wina w Ciało i Krew Pańską oraz ich spożycie, drudzy przez uczestniczenie we Mszy św. i przyjęcie Komunii św. ${ }^{11}$ ).

\section{Przestroga przed niegodna Komuniq święta (w. 27-34).}

Przypomnieniem Wieczerzy Pańskiej pragnął św. Paweł pouczyć Koryntian o wewnętrznym przygotowaniu się do Uozty Eucharystycznej i godnym uozestniczeniu w niej. „Nie możecie być uczestnikami stołu Pańskiego i czartowskiego" (1 Kor. 10, 21) pisał Apostoł, bo poganie składając ofiarę demonom wchodzili $z$ nimi w jakiś związek, a Koryntianie jako chrześcijanie, uczestnicząc w ofierze Eucharystycznej i spożywając Ciało i Krew Pana Jezusa, szczególnie w. głęboki ¡i żywotny spośb́b zespalają się ze Zbawicielem. Jak w Starym Testamencie przez ofiarowanie i spożycie Baranka Wielkanocnego łączyli się uczestnicy uczty paschalnej węzłami pokrewieństwa, tak w Nowym Testamencie ofiarowanie i spożycie Baranka Bożego ma być podstawą nowego pokrewieństwa, nowejj spójni naldprzyrodzonej, którą

10) Szczególową analizę kontrowersji teologów na soborze trydenckim co do jedności ofiary krzyża i Mszy šw. przedstawił nam Ks. St. Frankl w artykułach: „Jeđność ofiary krzỳża i ołtarza w świetle nauki soboru trydenckiego“ (Collectanea Theologica, Lwów 1938 f. 4. str. 397-437) i „Rola Kard. Seripandy w trydenckim dekrecie o Mszy św." (Coll. Theol. 1938 f. 1, str. 115-133).

11) Por. naukę Piusa XII co (tłum. Wierusz-Kowalskiego, Kielt nym Ciele Chrystusa", str. 68. (" $\because j$ kwestii w Encyklice "Mediator Dei“ i. 3, str. 60-66) i w Encyklice o ,MistyczKs. St. Brossa, Londyn 1945). 
odzwierciedlił Jezus słowami: ,kto pożyur moje ciało i pije moja krew, we mnie mieszka, a ja.w nim" (Jan 6, 57).

Św. Paweł jest pierwszym egzegetą słów Pana Jezusa o Najświętszym Sakramencie, egzegetą natchnionym. On dobrze zrozumiał istotę Eucharystii i działalność Jej w duszy ludzkiej. Pod wpływem sakramentalnego obcowania $z$ Chrystusem następuje w duszy pewien asymilacyjny proces, podobny do tego, jaki ma miejsce przy zwyczajnych pokarmach, lecz tylko w odwrotnym kierunku, podczas gdy cząsteczki pokarmu przechodzą w części ludzkiego ciała, to Chrystus Eucharystyczny pozoștając na swym poziomie podnosi człowieka do Siebie, przekształcając go do pewnego stopnia na wlasną modłę. Opanowuje On rozum i wolę człowieka i tak podbija całe jego nastawienie duchowe, że człowiek może powiedzieć: ,żyje już nie ja, ale żyje we mnie Chrystus ${ }^{6}\left(\right.$ Gal. 2, 20) $\left.{ }^{12}\right)$.

Wewnętrzne zatem, osobiste przygotowanie się do uczestniczenia w uczcie Eucharystycznej, w' myśl wskazań św. Pawła, jest rzeczą nieodzowną. Albowiem jak-na Wieczerzy Wielkoczwartkowej, tak i teraz na odtwarzanej przez Koryntian Uczcie, dzięki przeistoczeniu zjawia się sam Zbawiciel wprawdzie w sposób tajemniczy, ale nie mniej prawdziwy i rzeczywisty, jako taki łączy się wewnętrznie $z$ nimi.

Moment psychologiczny Eucharystii, uwzględniony tu przez Apostoła, posiada wielkie znaczenie dla życia indywidualnego $\mathrm{i}$ społecznego. Świadomość bezpośredniej obecności Chrystusa skłania do godnego przygotowania się i uczestniczenia w tajemnicach świętych.

- Warunkiem odpowiedniego przyjmowania Eucharystii i hołdu dla Niej jest w myśl nauki Apostoła ozyste serce: „Niech czlowiek zatem bada samego siebie i tak niech pozywa ten chleb $i$ z tego kielicha niech

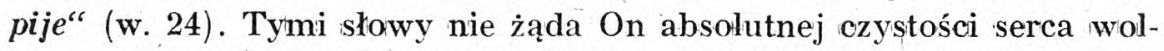
nego od wszelkiej słabości i niedoskonałości w chwili przystępowanịa do stołu Pańskiego, lecz przestrzega przed zawinionym zaniedbaniem przygotowania się do Komunii św. Kto nie bada serca (spowiedź, żal doskonały $)$, nie tylko w myśl nauki św. Pawła, nie otrzyma łaski Bożej płynącej z Eucharystii, lecz znieważa Najświętszy Sákrament, narażając się na karę sprawiedliwości Bożej (w. 27). Kto nịe chce zasłużyć na nią, niech częstó wgląda we własne sumienie, sądząc siebie, a nie bliźniego (w. 31). Czasem również Bóg używa kary, jako środka wy-

12) Zob. Ks. Frankl St.: ,Znaczenie scielna“, Lwów, 1939, str. 354 i n.). 
chowawczego, aby przestrzec nas przed nieszczęściem i uchronić od potępienia.

Pod wpływem nadprzyrodzonej działalności Eucharystii chrześcijanie zespalają się wewnętrznie z Chrystusem, poznając coraz lepiej myśli Jego, usuwając ze swych indyiwidualnych pojęć to, co nie godzi się $\mathrm{z}$ altruizmem Zbawiciela i kształtują się $w$ jeden wielki żywy organizm, - ,w jedno ciało, w którym każdy z osobna jeden drugiego członkami“ (Rzym. 12, 15).

Jest bowiem przyjętym zwyczajem, opartym na głębokich prawach psychologicznych, że wspólny posiłek wyraża duchową solidarność pewnego grona osób i służy do pogłębienia i spotęgowania tej solidarności. Eucharystia przez Mszę św. i Komunię św. dokonuje prawdziwej i doskonałej solidarności naszej z Chrystusem oraz miedzy poszczególnymi członkami Jego Ciała Mistycznego. Msza sw. zespala raczej zewnętrznie, Komunia św. zaś konsoliduje wewnętrznie, tworząc jeden żywy organizm mistyczny ${ }^{13}$ ). Eucharystia za tym jest Sakramentem kat" exochen społecznym - „Eucharistia est symbolum radix atque principium catholicae unitatis" (A. S._S. 1912, str. 615) ${ }^{14}$ ).

Na moment społeczny Eucharystii zwrócił szczególnie uwage św. Pawel, gdy wykładał Koryntianom o Ostatniej Wieczerzy, wskazując na nią jako jedyne lekarstwo na ich niedomagania.

Analizując tekst eucharystyczny św. Pawła; widzimy w nim usiłowanie realizacji czynnej miłości w życiu indywidualnym i społecznym pierwszych chrześcijan. Zwróceniem uwagi na moment psychologiczny of iarniczy i społeczny Eucharystii chciał wskazać Koryntianom św. Pawel, gdzie mają się uczyć miłości bratniej. Apostoł znał dobrze naturę ludzką z jej dobrymi i złymi stronami, taką samą widział juź u Koryntian, któnzy pełni pogańskich nawyków, jak egoizm, partyjnictwo i skłonność do życia rozpustnego, z trudem przeobrażali się w prawdziwych wyznawców Chrystusa. Św. Paweł widział w Eucharystii antidotum na te ułomności, w niej bowiem najbardziej odzwierciedlała się miłość Boża, z której zrodziła się ofiara krzyża. Uczta eucharystyczna zatem miała być dla chrześcijan szkołą ducha ofiary i miłcści, aby urzeczywistnić pierwsze i największe przykazanie głoszone przez Chrystusa. Szczególniejsze znaczenie jego podkreślił Jezus w mowie pożegnalnej słowami: „Po tyn poznaja wszyscy, żeście uczniami

${ }^{13}$ ) Porównaj: Ks. Mądr. 12, 22, Jud. 8, 27, 2 Mach. 6, 12 i znaczenie słowa: ,pa i deu o“ użyte przez śv. Bawla (Strack Billerbeck, op. c., str. 445.

$\left.{ }^{14}\right)$ Ks. Frankl: a. c. str. 374. 
moimi, jeśli milość mieć będziecie jedni ku drugim“ (Jan 13, 35). Wüdać od razu, że chodzi tu Zbawicielowi o c $\angle y n n a ̨$ i ofilarną miłość, którą nazywa prawem nowym i prawem swoim, $\downarrow$,przykazanie nowe daję wam, abyście $i$ wy wzajemnie się miłowali" (Jan 13, 34). „A nade wszystko miejcie trwałą miłość jedni ku drugim, bo miłość osłania mnóstwo grzechów. Bądźcie gościnni jedni dla drugich bez szemrania“ (1 Piotr 4, 8 i 9). „Cóż pomoże, bracia moi, jeśliby kto mówił, że ma wiarę, ale uczynków by nie miał?... I jesliby brat i siostra nie mieli ubrania i potrzebowali codziennej żywności, a ktoś powiedziałby im: Idźcie w pokoju, ogrzejcie się i naísyćcie, a nie dalibyście im tego, czego ciało ich potrzebuje - cóżby to pomogło?" (Jakub 2, 14-16). ,Każdy, kto nie jest sprawiedliwy i nie miłuje brata swego, nie jest z Boga, albowiem ta jest nowina, którąście słyszeli od początku, abyście się wzajemnie miłowali... Przez to poznaliśmy miłość Boga, że oddał za nas życie sswoje i my winniśmy życie oddać za braci. Kto by miał majętność tego świata, a widziałby brata swego w potrzebie i zamknąl przed nim serce swoje, jakże może w nim przebywać miłość Boża?... Nie miłujmy słowem, ani językiem, ale uczynkiem i prawdą“ (1 Jan $3,10-11$ i $16-18$ ).

W ten sposób właśnie zrozumieli naukę Chrystusową Jego uczniowie i tak jej nauczali. Tymi zasadami przejął się św. Paweł, a praktykując je w pełni, chciał je wpoić głęboko w umysły Koryntian. Dowodem tego są zorganizowane uczty eucharystyczne, których celem było nie tylko przypominanie tajemnic Bożych, lecz i pomoc charytatywna, polegająca nie na miłości zdawkowej, wyrażająca się często w słowach pociechy czy jałmużny, lecz na zorganizowanej miłości i sprawiedliwości społecznej. Specjålne cechy miłości Nowego Zakonu, która nie była znaną w starożytności i różniła się swym dynamizmem od miłości Starego Zakonu, podał nam św. Paweł w trzynastym rozdziale pierwszego lisfu do Koryntian. Miłość ta staje się osią, około której obracać się będzie rozwój chrześcijaństwa, odnowienie i odbudowa zupełna pogańskiego społeczeństwa.

Ks. WŁADYSLAW SMEREKA.

15) Zob. Scheeben J. M. Die Mysterien des Christentums, Wiesbaden, 1925, str. 343 i n. 